\title{
HYDRAULIC DESIGN OF AN AQUEDUCT AND ITS NECESSITY IN RAJOURI TOWN IN JAMMU AND KASHMIR
}

\author{
Yawar Mushtaq Raina ${ }^{1}$, Sajjad Ahmed ${ }^{2}$, Zuhaib Zahoor Shawl ${ }^{3}$, Ajaz Ahmed ${ }^{4}$ \\ ${ }^{1}$ Junior Engineer Public Works ( $R \& B$ ) Department, Government of Jammu \& Kashmir, India \\ yawarraina35@gmail.com \\ ${ }^{2,3}$ Research Scholar, GIMT, Kurukshetra, Haryana, India \\ sajjadmughal40@gmail.com,zuhaibshawl@yahoo.in \\ ${ }^{4}$ Faculty, University Polytechnic, Baba Ghulam Shah Badshah University, Rajouri, Jammu \& Kashmir, India \\ khanajaz00786@gmail.com
}

\begin{abstract}
Aqueduct is the Cross drainage arrangement which make the route of water from one side of drain to the other. Most of the Rajouri town is hilly and semi-hilly belt. At Rajouri about 9000 hectares areas of land remain deprived of irrigation facilities. The main aim of the paper is to present the hydraulic design of aqueduct proposed over Darhali River in Rajouri town and explain as to why aqueduct was required in this area. To assist the growth of crops in areas adjoining to Darhali River construction of Aqueduct from left bank to Right bank of River was projected. Aqueduct of 6 X $9.5 \mathrm{~m}$ span was proposed to be constructed. Substructure of the Aqueduct consists of the abutments, five piers and substructure of an R.C.C trough of internal size $2.0 \mathrm{~m} \times 2.3 \mathrm{~m}$. Foundation of abutment and piers were escalated below the Scour depth level of $4 \mathrm{~m}$ to avoid erosion and consequent damage to the structure via silting and erosion. The estimated cost of the structure was near about 90 lacs. It was found that rising of aqueduct structure shall boost farming in this area besides improving livelihood of respective land owners. The overall irrigation system of the town shall improve by constructing such a structure which was dependent mostly on rainfall.
\end{abstract}

Keywords: Cross Drainage Works, Aqueduct, Rajouri, Canal, Drainage, Hydraulic Design, Irrigation $* * *$

\section{INTRODUCTION}

Cross drainage works are the hydraulic structures which are constructed to allow the passage of canal water from one side of the drainage to the other (Punmia et al 2009). The passage of canal water from one side to the other is done either by allowing the water to go over the drainage or by allowing it to go under the drainage water. Sometimes canal water and the drainage cross each other at the same level (Punmia et al \& Garg 2009). Depending upon how canal water crosses the drainage, cross drainage works are classified into three types as: Canal over the drainage, Canal under the drainage and canal at the same level as that of drainage. When canal passes over the drainage, the cross drainage works which are constructed are either Aqueduct or syphon Aqueduct (Punmia et al \& Garg 2009). When canal is allowed to go under the drainage the cross drainage works constructed are either Canal syphon or Super passage (Arora , 2009). Sometimes canal and drainage water meet at the same time. In that case level crossing is provided. The relative bed levels, water levels, and discharge of the canal and the drainage are the primary factors which govern and dictate the type of cross drainage work. Aqueducts are further classified as type I, type II and type III aqueduct. Here type III aqueduct was provided because as the drainage was very small drain.

The canal is diverged and then is allowed to pass the drainage then this canal water ultimately benefits the land on other side of the drainage( lacey, 1934). The canal water passes through a trough which is generally an R.C.C or steel. The section of canal normally is kept trapezoidal in shape as it is best among hydraulic sections of lined canal (Swamee et al 2000). The construction of aqueduct is similar to that of bridge (Chen \& Duan, 2014, Punmia et al \& Garg 2009). Aqueduct consist of two parts sub structure and super structure (Sharma and Sharma, 2008). Substructure consists of piers, abutments, foundations (Tonias 1994). Super structure consists of slab and trough (Punmia et al \& Garg 2009). However if possible these cross drainage structures should be avoided. The aqueduct also facilitates water transportation in developed countries (Angelakis et al 2009) besides aiding the irrigation facilities.

\section{Study Area}

Rajouri used to be part of Poonch district but on 22 September1967. It was separated from poonch district and on 1st January1968 it was officially declared as the separate district covering an area equal to about $2630 \mathrm{sq} \mathrm{km}$. Rajouri is also known as Rajapuri or the land of kings. As per survey of india Rajouri lies between latitudes 330000'00" $\&$ $330035^{\prime} 20^{\prime \prime}$ North and longitudes 74'8'00" \& 7442'30" East. It is located at an elevation of about $562-4800 \mathrm{~m}$ above mean sea level and is surrounded by famous pir-panjal hills. The river flowing through Rajouri town comes from Darhal and Thanamandi, meeting each other near Darhali Bridge at Kheora (Raina and Alam, 2014, Raina and Anjum 2015, Aslam et al, 2015), where the aqueduct is proposed to be constructed. Temperature on the average varies from 7 
degree Celsius to 40 degree Celsius but area is generally cooler in winters. The average annual rainfall is $769 \mathrm{~mm}$. Figure 1 and 2 Shows map of Rajouri and its hydrogeology.

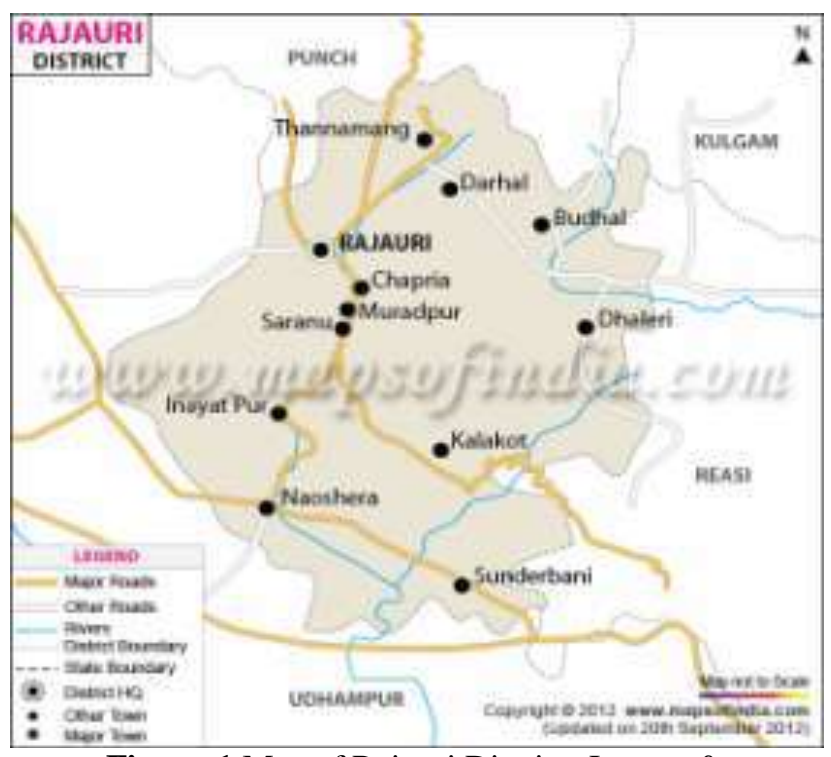

Figure-1 Map of Rajouri District, Jammu \&

\section{Kashmir, India (Source: Maps of India)}

In the state Jammu and Kashmir district Rajouri is one of the most important agricultural district having 7 blocks. Out of the seven blocks of district Rajouri, Nowshera, Sunderbani, Kalakote and Thanamandi are impotant agricarian blocks. Wheat is the major Rabi crop but along with wheat, maize and rice are the major Kharif crops grown in these blocks. Rajouri town does not have well developed irrigation system The per hectare yield of crops in this district is less as compared to other parts of state due to high weed infestations. Total area of the Rajouri is 253340 hectares of which 52,973 hectares are cultivable $(20 \%)$. Out of the cultivable land, 7721 hectares is irrigated (about 14\% of cultivable area $3 \%$ of the total geographical area). Table 1 shows the crops grown in district Rajouri.

Table-1: Crops grown in district Rajouri.

\begin{tabular}{|l|l|l|}
\hline S.no & Crop & Percentage(\%age) \\
\hline 1 & Rice & 6 \\
\hline 2 & Bajra & 0.25 \\
\hline 3 & Maize & 46 \\
\hline 4 & Wheat & 42.39 \\
\hline 5 & Barley & 0.018 \\
\hline 6 & Millet & 0.10 \\
\hline 7 & Pulses & 0.43 \\
\hline 8 & Sugarcane & - \\
\hline 9 & Fruit \& Vegetables & 0.069 \\
\hline 10 & Oil seeds & 1.5 \\
\hline
\end{tabular}

Most of the area is hilly and semi-hilly belt which is deprived of irrigation facility. Ans and Rajal canal is the only source of canal through which irrigation is done but that covers area of Budhal division only irrigating only 660 hactares of land. Construction of aqueduct is under way in Nowshera as well. Except canals wells also act as a source of irrigation but they contribute in very little amount. Irrigation in this area is also done mostly natural ways which include rainfall the sources by which irrigation is done in this area are given in table 2.

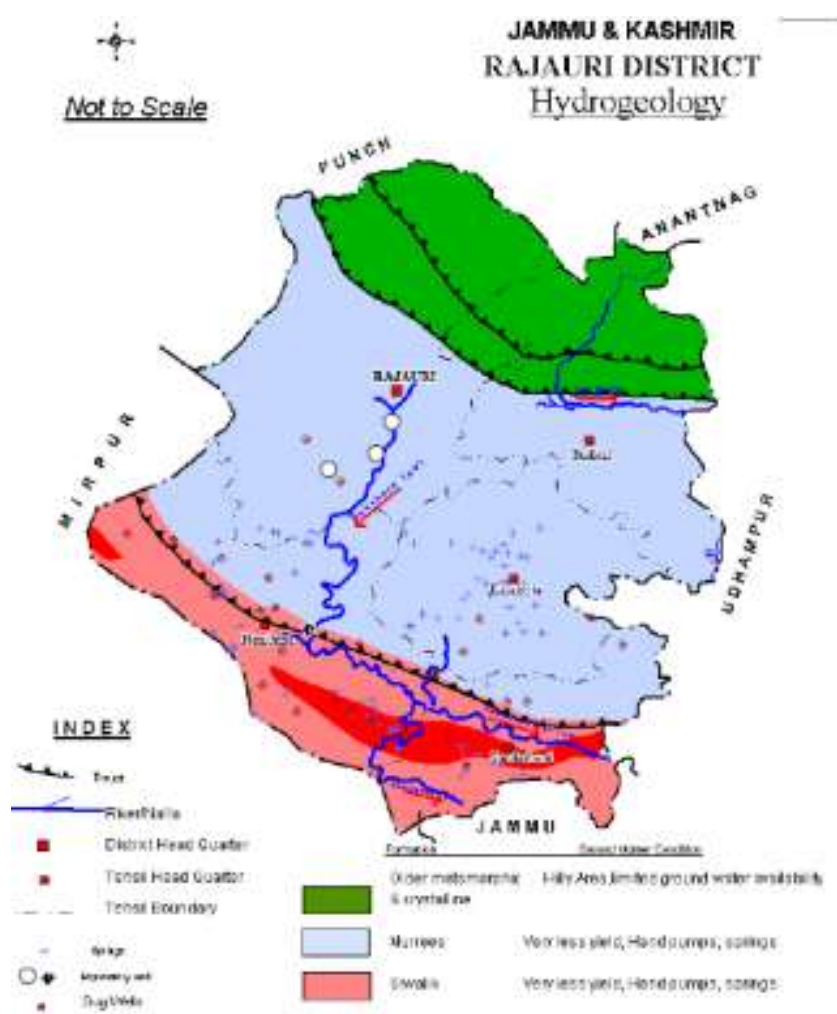

Figure-2 Map of Rajouri District, Showing Hydrogeology, (Source: Ground water information booklet Rajauri district)

Table 2 Irrigation by different sources

\begin{tabular}{|l|l|}
\hline Net Area Irrigated & 727 hectares \\
\hline Canals & 660 hectares \\
\hline Wells & 27 hectares \\
\hline Other Sources & 40 hectares \\
\hline Gross Area Irrigated & 800 hectares \\
\hline Canals & 680 hectares \\
\hline Wells & 50 hectares \\
\hline Other Sources & 70 hectares \\
\hline
\end{tabular}

Other then the above mentioned sources most of the paddy area is irrigated through khuls in Thanna, Behrote, Palma and sources of irrigation are Nullah Thanna, Nallah Ans, River Rajauri and Nullah Kalakote. One more aqueduct is proposed to be at kheora over Darhali River so that the land which remains deprived of irrigation gets the necessary water which not only will help in raising the crops but will also improve the financial situation of many farmers. Besides assisting the land owner.

\section{MATERIALS AND METHODS}

The material used in the construction of aqueduct was cement, course aggregate, sand, water and steel. Then the hydraulic and structural was done though here only hydraulic design is presented. Hydraulic design includes the 
design canal section, determining the highest flood discharge and highest flood level of the river, the design of drainage waterway, design of canal waterway which included design of transition and calculation of head losses at critical sections was done. Besides this design of guide banks, launching apron was also done. Scour depth was also determined by formula recommended by Indian standard. Structural design was done in accordance to IS 456:2000. Design of transition was done using Mitra method (Vittal and Chiranjeevi 1983), where as head losses were calculated using Darcy (Moody,1944) and Manning's formula (Dooge, 1989).

Current meter was used to find out velocity of drainage. Figure 3 shows the current meter.

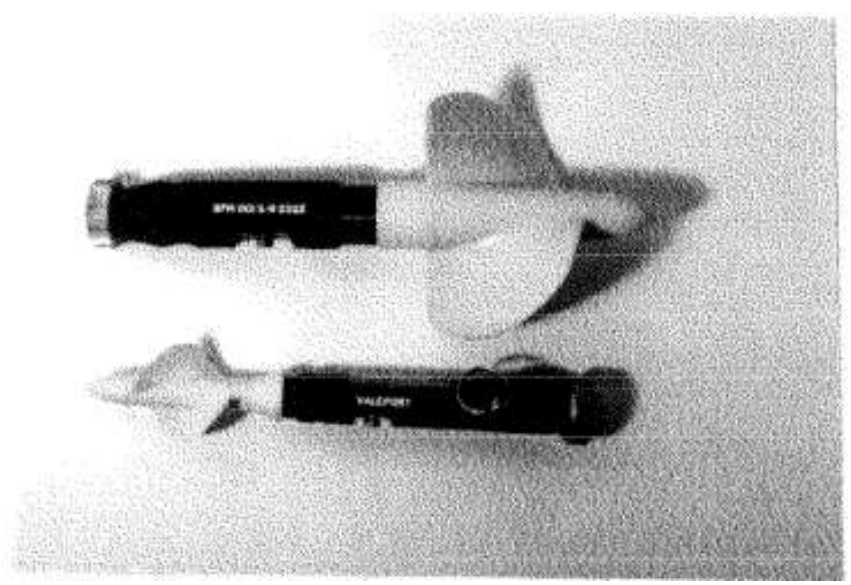

Figure 3: Current meter

A perfect current meter, whether mechanical or electromagnetic, should react right away and time after time to any change in water velocity, and should accurately register the desired velocity component. Also it should be sturdy, easily maintained, and simple to use Mechanical current meters compute velocity by interpreting linear motion into angular motion (Fulford et al 1994)

\section{RESULTS AND DISCUSSIONS}

Design of Aqueduct

The design of Aqueduct includes hydraulic design and structural design. Here only the hydraulic design is presented.

\section{Design of canal Section}

The design of Aqueduct starts with the design of canal. A canal a non-natural watercourse constructed to permit the passage of boats or ships or to transmit water for irrigation. Since the best cross section of the canal is trapezoidal for lined canals (Swamee et al 2000), here the trapezoidal cross section has been chosen. Applying the general method of design of alluvial lined channels the constant width and depth of alluvial canals with trapezoidal shape for a given set of water discharge, channel slope, sediment size, and side slope, F.S.L, Velocity etc are calculated (Chaang, 1980 and chitale, 1994). Table 3 shows Hydraulic design of Canal
Table 3- Hydraulic design of Canal

\begin{tabular}{|l|l|}
\hline Hydraulic Elements & Value \\
\hline Bed width of canal & $4 \mathrm{~m}$ \\
\hline Canal Water depth & $2 \mathrm{~m}$ \\
\hline Bed Slope of the channel & 1 in 3110 \\
\hline Free board & $0.3 \mathrm{~m}$ \\
\hline Fully supply level & $1002.685 \mathrm{~m}$ \\
\hline Full supply discharge & 10 Cumecs \\
\hline Canal bed level & $100.685 \mathrm{~m}$ \\
\hline Velocity & $0.8 \mathrm{~m} / \mathrm{sec}$ \\
\hline
\end{tabular}

The hydraulic design of the Darhali Nallah over which this canal will pass was done, in this design discharge and HFL of the Nallah was determined by calculating the velocity of river. The discharge was calculated using the continuity equation of discharge by first determining the cross sectional area which was $124.915 \mathrm{~m}^{2}$ calculated of the river and then multiplying it by velocity which was found out by current meter (Govers, 1992) and H.F.L was determined by consulting the locals and taking data of past 50 years, details of elements of drainage are shown in the table 4. The average velocity of the drainage was found to be $5.70 \mathrm{~m} / \mathrm{sec}$. Slope was calculated from L-Section of the drainage, it was found to be $3.86 \%$. Canal bed level was $1000.685 \mathrm{~m}$ and the highest flood level (H.F.L) of drainage was $999.485 \mathrm{~m}$. So Canal bed level was more than highest flood level (H.F.L) of drainage, an aqueduct was proposed constructed. The other design details of aqueduct are presented as follows

Table 4- Design details of Darhali Nallah

\begin{tabular}{|l|l|}
\hline Hydraulic Elements & Value \\
\hline High flood discharge & 712 Cumecs \\
\hline Highest flood level & $999.485 \mathrm{~m}$ \\
\hline
\end{tabular}

\section{Design of drainage Waterway}

Waterway is defined as the canal, river or other water body serving as a route or way of travel or transport (Broad, 1992) Table 5 shows some details of design of drainage water way

Table 5: Design of drainage water way

\begin{tabular}{|l|l|}
\hline Total water way & $62.5 \mathrm{~m}$ \\
\hline Clear Water way & $57.6 \mathrm{~m}$ \\
\hline Piers & 5 nos of $1 \mathrm{~m}$ each \\
\hline
\end{tabular}

Design of canal waterway

Canal waterway can be defined in a similar way as that of drainage waterway

\section{Transition design}

Transition in channels is defined as the change in cross section of canal (Punmia et al 2009, Garg 2009).Design of transition in both expansion and contraction was done using Mitra's method and is shown in table 6 
Table 6: Design of transitions

\begin{tabular}{|l|l|l|}
\hline S.No & Design Feature & Value \\
\hline 1 & Length of Expansion transition & $3 \mathrm{~m}$ \\
\hline 2 & Length of Contraction transition & $2 \mathrm{~m}$ \\
\hline 3 & Splay in Contraction & $2: 1$ \\
\hline 4 & Splay in Expansion & $3: 1$ \\
\hline 5 & Splay length in Contraction & $5 \mathrm{~m}$ \\
\hline 6 & Splay length in Expansion & $8 \mathrm{~m}$ \\
\hline
\end{tabular}

\section{Head losses at various levels at different section}

Head losses in the pipes and networks hydraulic delegate the irreparable loss of pressure energy, that experience a liquid or a gas as it passes through a conduit, or another fitting of fluid network (Hooper, 1981).The head losses, reduced levels and velocity of flow at different sections of canal were calculated and are shown in table 7. The head losses calculated at different sections as shown in table were started from section 4-4. Initially trapezoidal section was chosen and velocity was found out after calculating the cross section elements. Then velocity head was calculated by formula given by equation 1

Table 7- Head loses at Various sections of canals

\begin{tabular}{|c|c|c|c|c|c|c|c|c|c|}
\hline S.No & Section & $\begin{array}{l}\text { Velocity } \\
\text { (m/sec) }\end{array}$ & $\begin{array}{c}\text { Velocity } \\
\text { Head } \\
\text { (m) }\end{array}$ & $\begin{array}{l}\text { Head } \\
\text { Loss } \\
\text { due to } \\
\text { friction } \\
\text { (m) }\end{array}$ & $\begin{array}{c}\text { Head } \\
\text { Loss } \\
\text { due to } \\
\text { Contra- } \\
\text { ction } \\
\text { (m) }\end{array}$ & $\begin{array}{l}\text { Head Loss } \\
\text { due to } \\
\text { Expansion } \\
\text { (m) }\end{array}$ & $\begin{array}{c}\text { R.L of } \\
\text { bed } \\
\text { (m) }\end{array}$ & $\begin{array}{c}\text { R.L of } \\
\text { Water } \\
\text { Surfac } \\
\text { e (m) }\end{array}$ & $\begin{array}{c}\text { R.L of Total } \\
\text { Energy Line(m) }\end{array}$ \\
\hline 1 & $4-4$ & 0.83 & 0.035 & - & - & - & 1000.68 & $\begin{array}{c}1002.6 \\
8\end{array}$ & 1002.72 \\
\hline 2 & $3-3$ & 2.5 & 0.31 & - & - & 0.085 & 1000.5 & 1002.5 & 1002.805 \\
\hline 3 & $2-2$ & 2.5 & 0.31 & 0.41 & - & - & 1000.91 & $\begin{array}{c}1002.9 \\
1\end{array}$ & 1003.22 \\
\hline 4 & $1-1$ & 0.83 & 0.035 & - & 0.05 & - & 1002.96 & $\begin{array}{c}1002.9 \\
6\end{array}$ & 1003.275 \\
\hline
\end{tabular}

R.L of bed was found out earlier and by adding depth of canal water R.L of water surface was found. Total energy line which is the sum of all the heads was found by adding velocity head to R.L of water surface. Then we proceeded to section 3-3 from here the canal gets expanded and hence there will be loss of head due to expansion, calculated by formula given by equation 2

From section 3-3 to 2-2 there was head loss due to friction which was calculated by Manning's formula given in equation 3. Similarly reduced levels at this section were also found out. From Section 2-2 to 1-1 the canal gets contracted and as a result of that there will be head loss due to contraction, which is calculated by formula given in equation 4 . Reduced levels were found in similar way.

\section{Formulae used}

$\mathrm{H}=\mathrm{V}^{2} / 2 \mathrm{~g}$.

Where $\mathrm{V}$ is velocity of flow at that section and $\mathrm{g}$ is acceleration due to gravity.

Head due to expansion, calculated by formula

$\mathrm{H}_{\mathrm{e}}=0.3\left(\frac{V_{3}^{2}-V_{4}^{2}}{2 g}\right)$.

Head loss due to friction from section 3-3 to 2-2 there is which was calculated by

$\mathrm{H}_{2}=\frac{\mathrm{N}^{2} \mathrm{~V}^{2} \mathrm{~L}}{\mathrm{R}^{4} / 3}$

Where $\mathrm{N}$ is Manning's coefficient $\mathrm{R}$ is hydraulic radius $\mathrm{V}$ is velocity of flow and $\mathrm{L}$ is length of the canal waterway

Head loss due to contraction, which is calculated by formula
$\mathrm{H}_{\mathrm{c}}=0.5 \frac{\mathrm{V}_{2}^{2}-\mathrm{V}_{1}^{2}}{2 \mathrm{~g}}$

The complete details of the head losses and other features of canal trough are given in figure 2

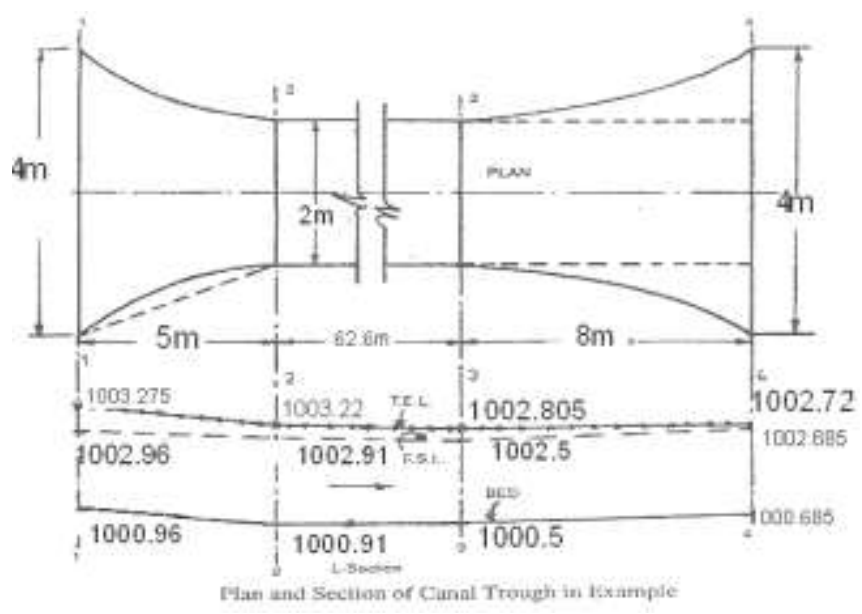

Figure 4- Head losses and R. L's at different sections

\section{Design of Guide banks}

They are provided to prevent the river from damaging railway formation, bridges and cross drainage or any other hydraulic structure (Przedwojski, 1995).

First of all length of Guide bank and radius of curved head both at the upstream and downstream end of the aqueduct were determined and are shown in the table 8 . The cross sectional details of guide banks are given in table 9 and figure 4 . 
Table 8: Length and radius of curved head of guide banks

\begin{tabular}{|l|l|l|l|}
\hline $\begin{array}{l}\text { Side of } \\
\text { aqueduct }\end{array}$ & $\begin{array}{l}\text { Length of } \\
\text { guide } \\
\text { bank(m) }\end{array}$ & $\begin{array}{l}\text { Radius of } \\
\text { curved } \\
\text { head(m) }\end{array}$ & $\begin{array}{l}\text { Sweep } \\
\text { angle }\end{array}$ \\
\hline Up stream & 78.13 & 34 & $130^{\circ}$ \\
\hline Down stream & 15.63 & 17 & $60^{\circ}$ \\
\hline
\end{tabular}

Table 9: The cross sectional details of guide banks

\begin{tabular}{|l|l|}
\hline H.F.L at aqueduct site & $999.485 \mathrm{~m}$ \\
\hline Free board & $1.5 \mathrm{~m}$ \\
\hline Top level of guide bank & $1000.985 \mathrm{~m}$ \\
\hline River bed level & $993.985 \mathrm{~m}$ \\
\hline Guide bank height above river bed & $7 \mathrm{~m}$ \\
\hline
\end{tabular}

The water face of the shank was pitched with one man stone weighing 0.4 to $0.5 \mathrm{KN}$ The rear slope of the shank was provided with vegetal cover. This was done for slope protection. Volume of stone required for pitching was found out to be $8.46 \mathrm{~m}^{3}$. Thickness of launching apron at the inner and outer edge was found out to be $1 \mathrm{~m}$ and $1.5 \mathrm{~m}$ respectively. Figure 4 shows cross section and plan of guide bunds

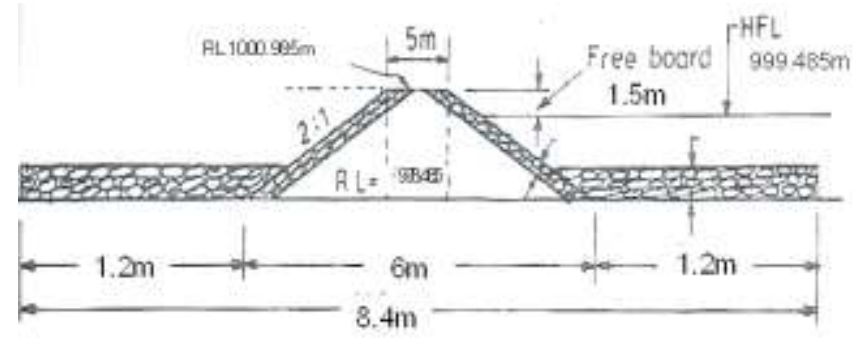

Cross-section (BB) of the curved portions of the Bell's bund,

Fig 5 -Cross section of curved portion of Bund

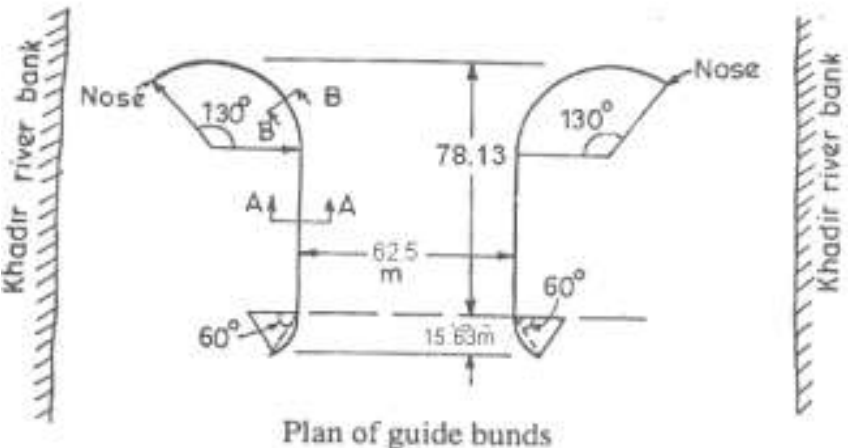

Fig 6- Plan of guide bunds.

Design of Launching Apron and Scour depth calculation Scour depth is the depth upto which soil erodes river bed (Lim, 1997). It is helpful in designing the foundation of a cross drainage work as the silting problems are controlled (Olsen, 1998). Scour depth at various sections and details of apron are tabulated in table 10. After that design of apron was done
Table 10: Scour depth and apron at various sections

\begin{tabular}{|l|l|l|}
\hline Section & $\begin{array}{l}\text { Scour } \\
\text { depth } \\
\text { below } \\
\text { river } \\
\text { bed } \\
(\mathrm{m})\end{array}$ & $\begin{array}{l}\text { Width of } \\
\text { launching } \\
\text { Apron } \\
\text { (m) }\end{array}$ \\
\hline $\begin{array}{l}\text { At the river bed from nose of the } \\
\text { guide bank and H.F.L }\end{array}$ & 4 & 1.2 \\
\hline $\begin{array}{l}\text { At the river bed at the transition } \\
\text { from nose to straight portion } \\
\text { and H.E.L }\end{array}$ & 0.8 & 1.6 \\
\hline $\begin{array}{l}\text { At the Shank of the guide bank and } \\
\text { H.F.L }\end{array}$ & 0.8 & 1.6 \\
\hline
\end{tabular}

\section{CONCLUSION}

The design of aqueduct was done and it was found that it is of great importance especially in areas like this where irrigation is done only by natural means and to some extent by wells. Rising of aqueduct structure shall boost farming in this area besides improving livelihood of respective land owners as 9000 hectares of land was found to remain deprived of irrigation. Aqueduct of $6 \times 9.5 \mathrm{~m}$ span was proposed to be constructed. Substructure of the Aqueduct consists of the abutments, five piers and substructure of an R.C.C trough of internal size $2.0 \mathrm{~m} \times 2.3 \mathrm{~m}$. Foundation of abutment and piers were escalated below the Scour depth of $4 \mathrm{~m}$ level to avoid erosion and consequent damage to the structure. Span of the aqueduct was $57.6 \mathrm{~m}$. The estimated cost of the structure was near about 90 lacs that was the only difficulty found that the project is pretty costly. Crops like rice wheat maize etc will grow by assistance of this aqueduct.

\section{REFRENCES}

[1]. Punmia, B. C., Pande Brij Basi Lal, Ashok Kumar Jain, and Arun Kumar Jain. Irrigation and water power engineering. Laxmi Publications, Ltd., 2009.

[2]. Garg, Santosh Kumar. Irrigation engineering and hydraulic structures. Khanna publishers, 2009.

[3]. Lacey, Gerald. "Uniform Flow in Alluvial Rivers and Canals.(Includes Appendices)."

[4]. Angelakis, A. N., D. Koutsoyiannis, B. A. Stewart, and T. A. Howell. "Encyclopedia of Water Science." (2003).

[5]. Swamee, Prabhata K., Govinda C. Mishra, and Bhagu R. Chahar. "Minimum cost design of lined canal sections." Water Resources Management 14, no. 1 (2000): 1-12.

[6]. Chen, Wai-Fah, and Lian Duan, eds. Bridge Engineering Handbook: Construction and Maintenance. CRC press, 2014.

[7]. Sharma, R. K., and T. K. Sharma. Irrigation engineering. S. Chand, 2008. 
[8]. Tonias DE. Bridge Engineering. Design, Rehabilitation, and Maintenance of Modern Highway Bridges. 1994.

[9]. Ground water information booklet Rajauri district, jammu and kashmir, north western Himalayan region Jammu, November 2009.

[10].Raina, Y.M. \& Alam, P. (2014):Wastewater Treatment and Management in Rural areas - A Case Study of Rajouri District, Jammu and Kashmir, India, International Journal of Development Research, 4 (11), 2266-2269.

[11]. Raina, YM \& Anjum, F. (2015): Analysis and Effect of Plastic and Biomedical waste on Rajouri Town, Jammu and Kashmir, India International Journal of Innovative Research in Science,Engineering and Technology,4(6),3904-3909.

[12].Aslam, Z., Raina, Y. M., \& Mohiuddin, I (2015). Characterization of Wastewater in Rajouri Town, Jammu And Kashmir, India, International journal of Engineering research and applications , 5(10),pp 69-79

[13].Dooge, J. C. I. "Manning Formula in Context." (1989).

[14].Moody, L. F. (1944). Friction factors for pipe flow. Trans. Asme, 66(8), 671-684.

[15]. Vittal, Nandana, and V. V. Chiranjeevi. "Open channel transitions: Rational method of design." Journal of Hydraulic Engineering 109, no. 1 (1983): 99-115.

[16].Standard, I., Plain and reinforced concrete-code of practice. New Delhi: Bureau of Indian Standards... 2000.

[17]. Chang HH. Stable alluvial canal design. Journal of the Hydraulics Division. 1980 May;106(ASCE 15420).

[18]. Board, Marine. Shiphandling simulation: Application to waterway design. National Academies Press, 1992.

[19].Fulford JM, Thibodeaux KG, Kaehrle WR. Comparison of current meters used for stream gaging. Fundamentals and advancements in hydraulic measurements and experimentation. 1994 Aug 1:37685.

[20]. Chitale, S. V. "Lacey divergence equations for alluvialcanal design." Journal of Hydraulic Engineering 120, no. 11 (1994): 1320-1326.

[21]. Chitale SV. Shape and size of alluvial canals. Journal of Hydraulic Engineering. 1976 Jul;102(7):1003-11.

[22].Govers G. Relationship between discharge, velocity and flow area for rills eroding loose, non-layered materials. Earth surface processes and landforms. 1992 Aug 1;17(5):515-28.

[23]. Hooper WB. The 2-K Method Predicts Head Losses in Pipe Fittings. Chemical Engineering. 1981 Jan 1; 88(17):96-100.

[24].Przedwojski, Bogusław, R. Błazejewski, and Krystian W. Pilarczyk. River training techniques: fundamentals, design and applications. AA Balkema, 1995.

[25].Lim, Siow-Yong. "Equilibrium clear-water scour around an abutment." Journal of Hydraulic Engineering 123, no. 3 (1997): 237-243.

[26].Olsen, Nils RB, and Hilde M. Kjellesvig. "Threedimensional numerical flow modeling for estimation of maximum local scour depth." Journal of Hydraulic Research 36, no. 4 (1998): 579-590. 